\title{
Species richness and abundance of bats in fragments of the stational semidecidual forest, Upper Paraná River, southern Brazil
}

\author{
Ortêncio-Filho, $H^{\mathrm{a}}{ }^{\mathrm{a}, \mathrm{b}}{ }^{\mathrm{a}}$ and Reis, $N \mathrm{R}^{\mathrm{c}}$ \\ ${ }^{a}$ Departamento de Biologia, Programa de Pós Graduação em Ecologia de Ambientes Aquáticos Continentais, \\ Universidade Estadual de Maringá - UEM

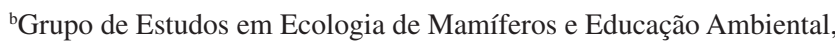 \\ Universidade Paranaense - UNIPAR, \\ Av. Brasil, 1123, CEP 87-200-000, Cianorte, PR, Brazil \\ ${ }^{\mathrm{c}}$ Universidade Estadual de Londrina - UEL, \\ CP 6001, CEP 86051-990, Londrina, PR, Brazil \\ *e-mail: henfilho@unipar.br
}

Received December 9, 2008 - Accepted March 22, 2009 - Distributed June 30, 2009

(With 2 figures)

\begin{abstract}
The Upper Paraná River floodplain is inserted in a region of the Mata Atlântica biome, which is a critical area to preserve. Due to the scarcity of researches about the chiropterofauna in this region, the present study investigated species richness and abundance of bats in remnants from the stational semidecidual forest of the Upper Paraná River, southern Brazil. Samplings were taken every month, from January to December 2006, using 32 mist nets with $8.0 \times 2.5 \mathrm{~m}$, resulting in $640 \mathrm{~m}^{2} / \mathrm{h}$ and totaling a capture effort of $87,040 \mathrm{~m}^{2} / \mathrm{h}$. In order to estimate the species richness, the following estimators were employed Chao1 and Jack2. During the study, a total of 563 individuals belonging to 17 species (Artibeus planirostris, Artibeus lituratus, Carollia perspicillata, Platyrrhinus lineatus, Sturnira lilium, Artibeus fimbriatus, Myotis nigricans, Desmodus rotundus, Artibeus obscurus, Noctilio albiventris, Phylostomus discolor, Phylostomus hastatus, Chrotopterus auritus, Lasiurus ega, Chiroderma villosum, Pygoderma bilabiatum and Lasiurus blossevillii) were captured. The estimated richness curves tended to stabilize, indicating that most of the species were sampled. Captured species represented 10\% of the taxa recorded in Brazil and 28\% in Paraná State, revealing the importance of this area for the diversity of bats. These findings indicate the need to determine actions aiming to restrict human activities in these forest fragments, in order to minimize anthropogenic impacts on the chiropterofauna.
\end{abstract}

Keywords: chiropterofauna, diversity, forest remnants, fragmentation.

\section{Riqueza e abundância de espécies de morcegos em fragmentos de floresta estacional semidecidual do Alto Rio Paraná, sul do Brasil}

\begin{abstract}
Resumo
A planície de inundação do Alto Rio Paraná está inserida em uma região de bioma Mata Atlântica, área crítica para preservação. Pela carência de pesquisas acerca da quiropterofauna da região, o presente estudo investigou a riqueza e abundância de morcegos em remanescentes de floresta estacional semidecidual do alto rio Paraná, sul do Brasil. As amostragens foram realizadas mensalmente, de janeiro e dezembro de 2006, com a utilização de 32 redes de neblina com $8,0 \times 2,5 \mathrm{~m}$, resultando em $640 \mathrm{~m}^{2} / \mathrm{h}$ e totalizando um esforço de captura de $87.040 \mathrm{~m}^{2} / \mathrm{h}$. Para a estimativa da riqueza foram utilizados os estimadores Chao1 e Jack2. Durante o estudo um total de 563 indivíduos pertencentes a 17 espécies (Artibeus planirostris, Artibeus lituratus, Carollia perspicillata, Platyrrhinus lineatus, Sturnira lilium, Artibeus fimbriatus, Myotis nigricans, Desmodus rotundus, Artibeus obscurus, Noctilio albiventris, Phylostomus discolor, Phylostomus hastatus, Chrotopterus auritus, Lasiurus ega, Chiroderma villosum, Pygoderma bilabiatum e Lasiurus blossevillii) foram capturados. As curvas de riqueza estimada tenderam à estabilidade, indicando que a maioria das espécies foi amostrada. As espécies capturadas representaram 10\% dos táxons registrados para o Brasil e 28\% para o estado do Paraná, revelando a importância dessa área para a diversidade de morcegos. Estes resultados indicam a necessidade de serem estabelecidas medidas para a restrição de atividades humanas nos fragmentos buscando-se minimizar os impactos antropogênicos sobre a quiropterofauna.
\end{abstract}

Palavras-chave: quiropterofauna, diversidade, remanescentes florestais, fragmentação. 


\section{Introduction}

The Upper Paraná River floodplain is located in the lastest stretch free of dams in the Paraná River within the Brazilian territory. Due to its location and importance as an ecological system, and the fact that is characterized as a region belonging to the Mata Atlântica biome, its preservation is critical. The anthropogenic activities in the area are related to deforestation of "várzea" environments for cropping, which usually involve the use of pesticides that may be carried to the waterbodies and to the marginal lakes, natural nurseries and feeding areas of several species (Vazzoler et al., 1997). This situation may generate an imbalance for the various components of the ecosystem, such as the chiropterofauna that has been threatened over the time, mainly by insecticides and deforestation (Reis et al., 2007). Fenton et al. (1992) stated that bats diversity is generally greater in conserved areas, where species can fulfill their different niches, when compared to altered areas by the habitat conditions.

Environmental alteration has caused severe decline in the number of species, with the loss of important elements in different trophic levels and changes in the structure and functioning of the ecosystem, resulting in the simplification of the structure of taxocenoses from different species, including bats (Aguiar, 1994). The ability to fly tends to mitigate such situations, since these animals may move between fragments and explore the environments in a complex way (Almansa et al., 1982), performing important roles within ecosystems, acting in the maintenance of several ecological processes (Eisenberg, 1989), as pollinators agents, seed dispersers (Van Der Pjil, 1957) and controlling natural insects populations (Goodwin and Greenhall, 1961).

Some studies conducted in the Paraná State reported species richness and abundance of chiropterans in areas of stational semidecidual forests. Reis et al. (1993) studied the Londrina region, followed by Reis and Muller (1995), and reported the importance of forests for the diversity and conservation of chiropterans in the same locality. For instance, Miretzki and Margarido (1999) carried out a survey of bats in the Estação Ecológica do Caiuá, Diamante do Norte city; Bianconi et al. (2004) studied forest remnants in the Fênix municipality; and Ortêncio Filho et al. (2005) surveyed bats in the Parque Municipal do Cinturão Verde in Cianorte municipality. The stational semidecidual forest, in the area of this study, is the forest formation in the Paraná State with the highest species diversity of bats and, among the species in this state ten are exclusive to this biome (Miretzki, 2003).

Information on the species richness of bats will contribute as a database and will provide subsidies for future conservation programs of local chiropterofauna. Therefore, the present study aimed to investigate the species richness and relative abundance of bats from the remnants from the stational semidecidual forest of the Upper Paraná River, southern Brazil.

\section{Material and Methods}

The study area includes the upper stretch of the Paraná River. The climate is classified as humid subtropical mesothermic (Cfa), with mean temperatures, in winter, inferior to $18{ }^{\circ} \mathrm{C}$, with uncommon frosts; and during the summer, above $22{ }^{\circ} \mathrm{C}$ and tendency of rainfall concentrations (Agostinho and Zalewski, 1996). The annual precipitation ranges from 1,400 to $1,500 \mathrm{~mm}$ (IAPAR, 1994).

The study was accomplished during one night per month, from January to December 2006, throughout the nocturnal period, beginning when the light intensity was lesser than 5 Lux, and ending when the same reached value higher than the previously cited, determined using the digital Minipa ${ }^{\circledR}$ luximeter (MLM-1010). Thus, between April and August, the number of sampling hours was 12 hours and in the other months it was 11 hours, except in January, when it lasted ten hours

In the beginning and in the end of the samples, air temperature was measured using psicrometer, and precipitation data were provided by the Instituto Tecnológico SIMEPAR. Air temperature ranged from $10.0{ }^{\circ} \mathrm{C}$ (August) to $31.3{ }^{\circ} \mathrm{C}$ (December), with annual mean of $21.5{ }^{\circ} \mathrm{C}$. The months between April and June were the drier ones, with the least precipitation in May (16.2 $\mathrm{mm})$. Greater precipitation was registered from January to March, peaking in December $(259.0 \mathrm{~mm})$. In general, higher precipitation coincided with warmer months.

The area is formed by stational semidecidual forest (Campos and Souza, 1997), composed mainly by the families Leguminosae (12.6\%), Poaceae (7.1\%), Euphorbiaceae $(5.4 \%)$, Rubiaceae (4.9\%), Cyperaceae (4.1\%), Myrtaceae (5.4\%) and Asteraceae (3.1\%) (Souza and Kita, 2002).

Samplings were performed in four fragments: 1) Field station $\left(22^{\circ} 45^{\prime} \mathrm{S}\right.$ and $\left.53^{\circ} 15^{\prime} \mathrm{W}\right)$ : degraded forest remnant of about 1.7 ha (Souza et al., 2005); 2) Mutum Island ( $22^{\circ} 48^{\prime} 18^{\prime \prime} \mathrm{S}$ and $\left.53^{\circ} 13^{\prime} 26^{\prime \prime} \mathrm{W}\right)$ : total area of 1,012 ha, with partial deforestation of its forest (Correa, 1998), sampling sites encompassed approximately $1.5 \mathrm{ha} ; 3)$ Araldo Forest (22 $47^{\prime} 37^{\prime \prime} \mathrm{S}$ and $53^{\circ} 19^{\prime} 03^{\prime} \mathrm{W}$ ): remnant with about 20.0 ha, formed by a marginal strip subjected to flooding during seasonal floods (Souza and Monteiro, 2005); and 4) Unida Farm $\left(22^{\circ} 41^{\prime} 01^{\prime \prime} \mathrm{S}\right.$ and $\left.53^{\circ} 17^{\prime} 34^{\prime \prime} \mathrm{W}\right)$ : altered forest remnant, isolated by a matrix for cultivation of exotic fruit species, pasture and natural regeneration, with 1.22 ha (Souza, 2004) (Figure 1).

To capture the bats, 32 mist nets were used, eight in each sampling site, with $8.0 \times 2.5 \mathrm{~m}$, resulting in $640 \mathrm{~m}^{2} / \mathrm{h}$ per hour and totaling a capture effort of $87.040 \mathrm{~m}^{2} / \mathrm{h}$ (Straube and Bianconi, 2002); the nets were set between 0.5 and $3.0 \mathrm{~m}$ from the ground to facilitate the capture of frugivorous phyllostomids that due to the higher food availability in the region, they are frequent in the stratum corresponding to the sub-forest (Pedro, 


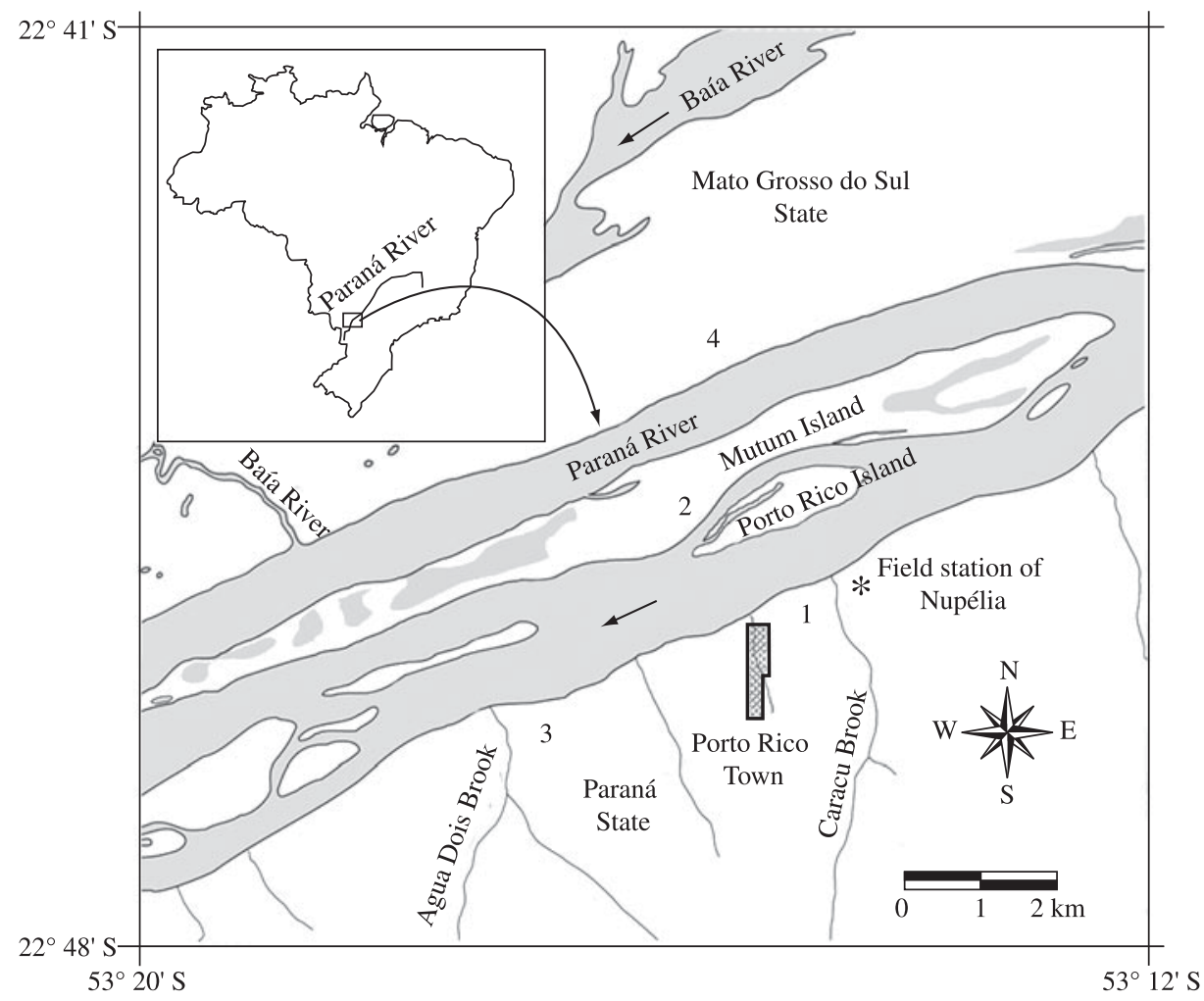

Figure 1. Area of captures with the respective selected sites in the Upper Paraná River floodplain: 1) Field Station, 2) Mutum Island, 3) Araldo Forest and 4) Unida Farm.

1998). The capture method were based on Greenhall and Paradiso (1968), with nets set in places with high preference of bats in their movements, as forest clearings, little busy roads, trails and waterways, and inspected every 15 minutes, following criteria of Reis (1984).

After the capture, the length of the forearm and the weight were taken and then the species identified. Two individuals from each species were deceased with an intraperitoneal dose of sodium tiopenthal (Ortêncio Filho et al., 2005), and fixed in formaldehyde $10 \%$ during 48 hours and, then preserved in alcohol 70\%. The individuals were identified using stereoscopic microscope, according to Vizoto and Taddei (1973), Jones and Carter (1976) and Gregorin and Taddei (2002), confirmed by Professor Adriano Lucio Peracchi (Universidade Federal Rural do Rio de Janeiro) and deposited in the Laboratório de Zoologia of Universidade Paranaense, Campus Cianorte. All captured bats were labeled with aluminum rings (Etiquetal-models 3.5 and 4.0), in their left forearm, allowing to identify possible recaptures.

In order to extrapolate the species richness of bats in the region of Porto Rico municipality, the EstimateS software (version 5.0.1) was used (Colwell, 1997), and the following non-parametric methods were employed Chao1 and Jack2 (Jackknife2).

\section{Results}

During the studied period, we capture 563 bats, belonging to 17 species. A total of 0.007 bats $/ \mathrm{m}^{2}$.h was sampled. Phyllostomidae presented the highest number of species (13), with the predominance of frugivorous (10), followed by two carnivorous species and one hematophagous (Gardner, 1977). Vespertilionidae was represented by the insectivores Lasiurus blossevillii, L. ega and Myotis nigricans, whereas Noctilionidae by Noctilio albiventris which consumes insects and fishes (Gardner, 1977) (Table 1).

The most frequent species in the samplings was Artibeus planirostris which totaled $24.2 \%$ of the captures, followed by A. lituratus and Carollia perspicillata (21.3\% each), Platyrrhinus lineatus (10.8\%) and Sturnira lilium $(7.5 \%)$. Together, these species accounted for $85.1 \%$ of all captured bats, whereas the remaining 12 species represented only $14.9 \%$ of the total. The study was marked by the low occurrence of some species, since $41.2 \%$ of the species presented number of captures equal or inferior to four individuals.

The curves of estimated species richness in relation to the curve of observed species indicated a trend to stability for the bat species captured in accordance 
Table 1. Bats captured in forest fragments from the Upper Paraná River, Brazil, between January and December, 2006.

\begin{tabular}{|c|c|c|c|}
\hline Taxa & $\begin{array}{c}\text { Number of } \\
\text { captures }\end{array}$ & $\begin{array}{c}\text { Relative } \\
\text { abundance }(\%)\end{array}$ & $\begin{array}{c}\text { Feeding } \\
\text { habit* }\end{array}$ \\
\hline \multicolumn{4}{|l|}{ PHYLLOSTOMIDAE } \\
\hline \multicolumn{4}{|l|}{ Desmodontinae } \\
\hline Desmodus rotundus (E. Geoffroy, 1810) & 7 & 1.2 & Hematophagous \\
\hline \multicolumn{4}{|l|}{ Phyllostominae } \\
\hline Chrotopterus auritus Peters, 1865 & 2 & 0.4 & Carnivorous \\
\hline Phyllostomus discolor Wagner, 1843 & 4 & 0.7 & Frugivorous \\
\hline Phyllostomus hastatus (Pallas, 1767) & 2 & 0.4 & Omnivorous \\
\hline \multicolumn{4}{|l|}{ Carolliinae } \\
\hline Carollia perspicillata (Linnaeus, 1758) & 120 & 21.3 & Frugivorous \\
\hline \multicolumn{4}{|l|}{ Stenodermatinae } \\
\hline Artibeus fimbriatus Gray, 1838 & 32 & 5.7 & Frugivorous \\
\hline Artibeus lituratus (Olfers, 1818) & 120 & 21.3 & Frugivorous \\
\hline Artibeus obscurus (Schinz, 1821) & 5 & 0.9 & Frugivorous \\
\hline Artibeus planirostris (Spix, 1823) & 137 & 24.2 & Frugivorous \\
\hline Chiroderma villosum Peters, 1860 & 1 & 0.2 & Frugivorous \\
\hline Platyrrhinus lineatus (E. Geoffroy, 1810) & 61 & 10.8 & Frugivorous \\
\hline Pygoderma bilabiatum (Wagner, 1843) & 1 & 0.2 & Frugivorous \\
\hline Sturnira lilium (E. Geoffroy, 1810) & 42 & 7.5 & Frugivorous \\
\hline \multicolumn{4}{|l|}{ VESPERTILIONIDAE } \\
\hline Lasiurus blossevillii (Lesson and Garnot, 1826) & 1 & 0.7 & Insectivorous \\
\hline Lasiurus ega (Gervais, 1856) & 2 & & \\
\hline Myotis nigricans (Schinz, 1821) & 22 & 0.2 & Insectivorous \\
\hline NOCTILIONIDAE & & 0.4 & Insectivorous \\
\hline Noctilio albiventris Desmarest, 1818 & 4 & 3.9 & Insectivorous \\
\hline Total & 563 & 100 & \\
\hline
\end{tabular}

*Gardner (1977)

with the employed method (Figure 2). The bats survey in the region of Porto Rico city reached between 70.2 (24.23 \pm 0.00$)$ for Jack 2 and $95.8 \%(17.75 \pm 1.42)$ for Chao1 of expected species, considering the limitations of the applied sampling method, that is, the set of the nets near the ground.

\section{Discussion}

The 17 captured species accounted for $10 \%$ of the species recorded in Brazil and 28\% in Paraná State (Reis et al., 2007). The present study registered lower values of species richness when compared to others carried out in this state, possibly due to the fact that these surveys used other capture methods in the other studies. For example, in the region of Londrina municipality, in 680 ha of forest remnants, 42 species were registered (Reis et al., 2008); in the 52,000 ha in the Telêmaco Borba municipality, 22 species were observed (Reis et al., 1999); and, in the 170,000 ha of Parque Nacional do Iguaçu, in the Foz do Iguaçu municipality, 26 species were sampled (Sekiama et al., 2001).
In the present study, we did not conducted samplings in shelters; thus, individuals of Molossidae, commonly found in these places or captured using other sampling gears, were not registered. Therefore, the number of sampled species in the forest fragments of the region of Porto Rico, which totaled about 26.8 ha from a floodplain region with 526,752 ha (Agostinho and Zalewski, 1996), revealed the importance of this area for the diversity of bats.

In contrast, values of species richness lower than we registered were verified in other studies performed in Northwestern Paraná State, such in the 1.427 ha from the Estação Ecológica do Caiuá, with 14 species (Miretzki and Margarido, 1999), 16 species in 703 ha of forest fragments in the Fênix municipality (Bianconi et al., 2004) and, in the Parque Municipal do Cinturão Verde de Cianorte, area of 312 ha, with 12 registered species (Ortêncio Filho et al., 2005). Sampling time (Santos, 2003) and effort (Straube and Bianconi, 2002) may also have influenced these results.

The predominance of Phyllostomidae (76\%) in the samples occurred due to the capture method which 

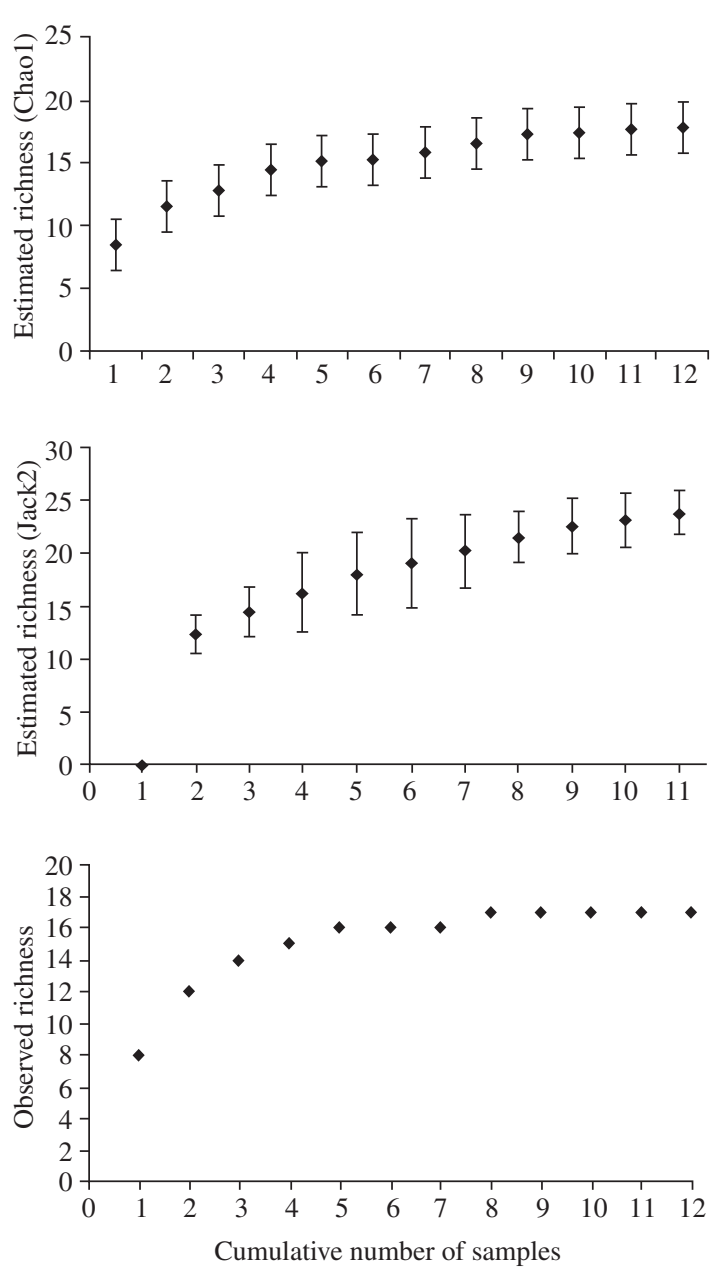

Figure 2. Estimated species richness for bat species in forest fragments from the Upper Paraná River, according to Chao1 and Jacknife2 estimators between January and December, 2006.

is characterized by the installation of the nets near the ground (Pedro and Taddei, 1997), more efficient in capturing frugivorous species from the sub-forest stratum, and carnivorous, which capture invertebrates or even small vertebrates, present in the foliage of the shrub layer (Fleming, 1982; Nowak, 1994). On the other hand, this family is the richest in the Neotropical region (Fenton et al., 1992), and their representatives do not have sharp ability to detect nets (Nowak, 1994).

The low diversity of Vespertilionidae (18\%) was also due to the capture method, since these animals easily perceive the nets (Greenhall and Paradiso, 1968). Similar situation explains Noctilionidae (6\%) which uses echolocation to capture insects and fishes (Nowak, 1994). As mentioned, the absence of individuals of Molossidae may be ascribed to the fact that these insectivorous fly high, above the canopy of trees (Greenhall and Paradiso, 1968), as well as because samplings in shelters were not conducted (Gregorin and Taddei, 2002).
The existence of few remnants, caused by habitat fragmentation (Mikich and Silva, 2001), may generate loss of species in the region due to anthropogenic changes in the habitats (Reis and Muller, 1995). This favors the increase in the density of bats as A. planirostris, A. lituratus, C. perspicillata, P. lineatus and S. lilium, which consume fruits (Gardner, 1977), common in the region. These species represented $85.1 \%$ of the total sampled at the expense of those demanding species, whose abundance was very low or even null. The predominance of some species in the study area is related to the fact that they are abundant in the Neotropical realm due to their diets which are composed by regionally common fruits (Medellín et al., 2000), represented by Solanaceae, Cecropiaceae, Moraceae and Piperaceae Families (Souza and Monteiro, 2005).

It must be highlighted that, for $53 \%$ of species, five or fewer individuals were sampled, which may suggest the fragility of C. auritus, P. discolor, P. hastatus, A. obscurus, C. villosum, P. bilabiatum, N. albiventris, L. blossevillii and L. ega to the region. Pires et al. (2006) argued that, due to low population densities, less abundant species are more susceptible to local extinctions or to restricted distribution, as in the case of the above mentioned species. In addition, it is important to emphasize the occurrence of bats associated to food availability, such as $C$. villosum, specialist in the consumption of Ficus (Zortéa, 2007).

Some species, such as A. lituratus, present a high integration with the environment, considering aspects linked to the occupation of time, space and food, which evidences high adaptive potential (Reis et al., 2000). These same authors argue that environmental changes may lead to great occupation by trophic generalist species, inducing the displacement of more sensitive species to other areas and, hence, decreasing the species richness in a fragment.

The low captures of $C$. auritus and P. hastatus (Phyllostominae) may be due to the fact that these large bodied animals present tendency to be poorly represented in perturbed areas (Medellín et al., 2000). Chrotopterus auritus, a large bodied carnivore (Nogueira et al., 2007), that acts as top predator, may disappear more quickly (Pires et al., 2006).

Desmodus rotundus, the only hematophagous species recorded, is characterized as the most common and abundant species with such feeding habit, and it is distributed throughout Brazil (Aguiar, 2007). The occurrence of this species in the studied region may be associated to the availability of food resource from wild origin, as well as cattle from farms close to our sampling sites.

In relation to bats from the Paraná State, some species were captured for the first time in the Northwestern region of this state. Phyllostomus discolor, was previously recorded only in the Northern region, A. obscurus (Eastern, Southwestern and Northern regions; Reis et al., 2008) and L. ega in the Northern region (Miretzki, 
2003). These findings point out the importance of these fragments, even modified.

Indeed, the studied area may be considered well surveyed, basing on the net captures. The results of the estimators suggest that our survey in the region of Porto Rico municipality reached between $70.2 \%$ (Jack2) and $95.8 \%$ (Chao1) of the total number of expected species, even considering the restrictions of the sampling method. Therefore, the use of other sampling techniques certainly would beget records of other species, especially those belonging to Vespertilionidae and Molossidae.

In the present study, the species richness estimators tended to the stability, however, the curve from the Chao 1 estimator presented such result faster than the other one. In the Jack 2 estimator, the curves stabilization followed the accumulation curve of observed species. Between the estimative of species richness obtained in the analysis, Jack2 presented a number of species greater than 24 . The Chao1, although had estimated only 17 species for the local, presented the greatest standard deviation, in spite of decreasing the result reliability, emphasized the chance of existing until 19 species for the area.

The estimators of species richness used here are based on the rarity quantification to determine diversity (Santos, 2003). Therefore, the species analysis with this characteristic is of fundamental importance to assure the reliability of the obtained results and, certainly, the capture method used interfered in the efficiency of sampling those species.

During the sampling period, some low abundant species, that could be considered as rare, were sampled: three Singletons (C.villosum, P. bilabiatum and L. blossevillii), three Doubletons (C. auritus, P. hastatus and L. ega), five Uniques ( $P$. bastatus, $P$. discolor, C. villosum, $P$. bilabiatum and L. blossevillii) and two Duplicates (L. ega and C. auritus). Nevertheless, the quantification of these species may be more associated to the capture method and to the characteristics of the species than to the low abundance of these organisms in the region. Some species may be abundant for the local, but, by the used method, it was not possible to sample them.

In the present study, considerable values of species richness and abundance of bats were verified, when compared to the other regions in the Paraná State, emphasizing the importance to conserve this area for the maintenance of this group diversity. Thus, it is important to restrain human activities in the fragments to retain the degradation of these environments, due to the occurrence of low abundant species. These results contribute for the knowledge about bats biology in the Northwestern region of Paraná State. The information produced suggests the need to accomplish conservation strategies focusing on the relevance to minimize the impacts in the area, since such condition may cause the loss of bat species diversity in the region.

Acknowledgements - We wish to express our gratitude to Universidade Estadual de Maringá and to Universidade Paranaense, by the financial support and encouragement; Aldair
Tavares de Souza, Aline Farias Zanetti, Danieli Carvalho Vieira, Danieli Pinto, Émerson Jamber, Gisele Camilloti Paulino, Gustavo Barizon Maranho, Loseni Budny, Marcelo Aparecido Marques, Regiane Anderson, Rosiane Rufino Fernandes, Sandra Mara Milani Nishimura and Sílvia Regina Ferreira by their participation and support in the field samplings, and we also thank Marcos Magalhães, Gledson Vigiano Bianconi, Cibele Maria Vianna Zanon and Luzia Cleide Rodrigues for suggestions and criticism.

\section{References}

AGOSTINHO, AA. and ZALEWSKI, MA., 1996. A planície alagável do alto rio Paraná: importância e preservação. Maringá: EDUEM; Nupélia. 100p.

AGUIAR, LMS., 1994. Comunidades de Chiroptera em três áreas da Mata Atlântica em diferentes estádios de sucessão: estação Biológica de Caratinga. Belo Horizonte: Universidade Federal de Minas Gerais. 93f. Dissertação de Mestrado.

2007. Subfamília Desmodontinae. In REIS, NR., PERACCHI, AL., PEDRO, WA. and LIMA, IP. (Eds.). Morcegos do Brasil. Londrina: Nelio Roberto dos Reis. p. 39-43.

ALMANSA, JC., MARTINEZ, LMAR. and ULARGUI, CI., 1982. Uso del espacio y movimientos en una comunidad de quiropteros neotropicales. Historia Natural, vol. 2, no. 21, p. $177-190$

BIANCONI, GV., MIKICH, SB. and PEDRO, WA., 2004. Diversidade de morcegos (Mammalia, Chiroptera) em remanescentes florestais do município de Fênix, noroeste do Paraná, Brasil. Revista Brasileira Zoologia, vol. 4, no. 21, p. $943-954$.

CAMPOS, JB. and SOUZA, MC., 1997. Vegetação. In VAZZOLER, AEA., AGOSTINHO, AA. and HAHN, NS. (Eds.). A planície de inundação do alto rio Paraná: aspectos físicos, biológicos e socioeconômicos. Maringá: EDUEM; Nupélia. p. 331-342.

COLWELL, RK., 1997. EstimateS 8.0: statistical estimation of species richness and shared species from samples. [S.L.]:[s.n.]. 22p. Use Guide. Available from: <viceroy.eeb.uconn.edu/ estimates>. Acesso in: 26 de Junho de 2008.

CORREA, GT., 1998. O uso do solo no arquipélago Mutum Porto Rico - alto rio Paraná, PR/MS. Maringá: Universidade Estadual de Maringá - UEM. 27f. Dissertação de Mestrado.

EISENBERG, JF., 1989. Mammals of the neotropics: the northern neotropics. Chicago: The University of Chicago Press. $449 \mathrm{p}$.

FENTON, MB., ACHARYA, L., AUDET, D., HICKEY, MBC., MERRIMAN, C., OBRIST, MK., SYME, DM. and ADKINS, B., 1992. Phyllostomid bats (Chiroptera, Mammalia) as indicators of habitat disruption in the neotropics. Biotropica, vol. 24 , no. 3 , p. 440-446.

FLEMING, TH., 1982. Foraging strategies of plant visiting bats. In KUNZ, TH. (Ed.). Ecology of bats. New York: Plenum Press. p. 287-326.

GARDNER, AL., 1977. Feeding habits. In BAKER, RJ., JONES Jr., JK. and CARTER, DC. (Eds.). Biology of the bats of the new world family Phyllostomatidae. Lubbock: Special Publications Museum Texas Tech University. p. 293-350. 
GOODWIN, GG. and GREENHALL, AM., 1961. A review of the bats of Trinidad and Tobago. Bulletim of the American Museum of Natural History, vol. 122, no. 3, p. 187-302.

GREENHALL, AM. and PARADISO, JL., 1968. Bats and bat banding. Bureau of Sport Fisheries and Wildlife Resource Publication, no. 72, p. 1-47.

GREGORIN, R. and TADDEI, VA., 2002. Chave artificial para identificação de molossídeos brasileiros (Mammalia, Chiroptera). Mastozoologia Neotropical, vol. 1, no. 9, p. 13-32.

Instituto Agronômico de Paraná - IAPAR, 1994. Cartas climáticas do estado do Paraná. Londrina: IAPAR. 45p.

JONES, JK. and CARTER, DC., 1976. Annotated checklist, with keys to subfamilies and genera. In BABER, RJ., JONES JR, JK. and CARTER, DC. (Eds.). Biology of bats of the new world family Phyllostomidae, part I. Lubbock: Museum Texas Tech. University. p. 7-38. Special Publications.

MEDELLÍN, RA., EQUIHUA, M. and ALMIN, MA., 2000. Bat diversity and abundance as indicators of disturbance in neotropical rainforests. Conservation Biology, vol. 6, no. 14, p. $1666-1675$.

MIKICH, SB. and SILVA, SM., 2001. Composição florística e fenologia das espécies zoocóricas de remanescentes de Floresta Estacional Semidecidual no centro-oeste do Paraná, Brasil. Acta Botanica Brasilica, vol. 1, no. 15, p. 89-113.

MIRETZKI, M., 2003. Morcegos do estado do Paraná, Brasil (Mammalia, Chiroptera): riqueza de espécies, distribuição e síntese do conhecimento atual. Papéis Avulsos de Zoologia, vol. 6, no. 43, p. 101-138.

MIRETZKI, M. and MARGARIDO, TCC., 1999. Morcegos da Estação Ecológica do Caiuá, Paraná (Sul do Brasil). Chiroptera Neotropical, vol. 1-2, no. 5, p. 105-108.

NOGUEIRA, MR., PERACCHI, AL. and MORATELLI, R., 2007. Subfamília Phyllostominae. In REIS, NR., PERACCHI, AL., PEDRO, WA. and LIMA, IP. (Eds.). Morcegos do Brasil. Londrina: Nelio Roberto dos Reis. p. 61-97.

NOWAK, RM., 1994. Walker's bats of the world. Baltimore: The Johns Hopkins University Press. 287p.

ORTÊNCIO FILHO, H., REIS, NR., PINTO, D., ANDERSON, R., TESTA, DA. and MARQUES, MA., 2005. Levantamento dos Morcegos (Chiroptera, Mammalia) do Parque Municipal do Cinturão Verde de Cianorte, Paraná, Brasil. Chiroptera Neotropical, vol. 1-2, no. 11, p. 211-215.

PEDRO, WA., 1998. Diversidade de morcegos em hábitats florestais fragmentados do Brasil (Chiroptera, Mammalia). São Carlos: Universidade Federal de São Carlos - UFSCAR. 128f. Tese de Doutorado.

PEDRO, WA. and TADDEI, VA., 1997. Taxonomic assemblage of bats from Panga Reserve, southeastern Brazil: abundance patterns and trophic relation in the Phyllostomidae (Chiroptera). Boletim do Museu de Biologia Mello Leitão, vol. 6, p. 3-21.

PIRES, AS., FERNANDEZ, FAS. and BARROS, CS., 2006. Vivendo em um mundo em pedaços: efeitos da fragmentação florestal sobre comunidades e populações animais. In ROCHA, CFD., BERGALLO, HG., SLUYS, MV. and ALVES, MAS. (Eds.). Biologia da conservação. São Carlos: RiMa. p. $231-260$.
REIS, NR., 1984. Estrutura de comunidade de morcegos da região de Manaus, Amazonas. Revista Brasileira de Biologia $=$ Brazilian Journal of Biology, vol. 44, no. 3, p. 247-254.

REIS, NR., LIMA, IP. and MIRETZKI, M., 2008. Morcegos do Paraná. In REIS, NR., PERACCHI, AL. and SANTOS, GASD. (Eds.). Ecologia de morcegos. Londrina: Nelio Roberto dos Reis. p. 143-148.

REIS, NR. and MULLER, MF., 1995. Bat diversity of forests and open areas in a subtropical region of South Brazil. Revista Ecologia Austral, vol. 5, no. 1, p. 31-36.

REIS, NR., MULLER, MF., SOARES, ES. and PERACCHI, AL., 1993. Lista e chave de quirópteros do Parque Estadual Mata dos Godoy e arredores, Londrina-PR. Semina, Ciências Biológicas/Saúde, vol. 2, no. 4, p. 120-126.

REIS, NR., PERACCHI, AL. and SEKIAMA, ML., 1999. Morcegos da fazenda Monte Alegre, Telêmaco Borba, Paraná (Mammalia, Chiroptera). Revista Brasileira de Zoologia, vol. 2, no. 16 , p. 501-505.

REIS, NR., PERACCHI, AL., SEKIAMA, ML. and LIMA, IP., 2000. Diversidade de morcegos (Chiroptera: Mammalia) em fragmentos florestais no estado do Paraná, Brasil. Revista Brasileira de Zoologia, vol. 3, no. 17, p. 697-704.

REIS, NR., SHIBATTA, OA., PERACCHI, AL., PEDRO, WA. and LIMA, IP., 2007. Sobre os morcegos brasileiros. In REIS, NR., PERACCHI, AL., PEDRO, WA. and LIMA, IP. (Eds.). Morcegos do Brasil. Londrina: Nelio Roberto dos Reis. p. 17-25.

SANTOS, AJ., 2003. Estimativas de riqueza em espécies. In CULLEN Jr., L., VALLADARES-PÁDUA, C. and RUDRAN, R. (Orgs.). Métodos e estudos em biologia da conservação $e$ manejo da vida silvestre. Curitiba: Ed. da UFPR; Fundação o Boticário de Proteção à Natureza. p. 19-41.

SEKIAMA, ML., REIS, NR., PERACCHI, AL. and ROCHA, VJ., 2001. Morcegos do Parque Nacional do Iguaçu, Paraná (Chiroptera; Mamalia). Revista Brasileira de Zoologia, vol. 3, no. 18 , p. $749-754$.

SOUZA, MC., 2004. Vegetação ripária. In: Universidade Estadual de Maringá, Nupélia/PELD. (Orgs.). A planície de inundação do alto rio Paraná: Site 6. Maringá: PELD/CNPq. Relatório anual 2004. Available from: <http://www.peld.uem. br/Relat2004/pdf/vegetaçao_riparia2004.pdf >. Access in: 04 de Novembro de 2007.

SOUZA, MC. and KITA, KK., 2002. Formações vegetais ripárias da planície alagável do alto rio Paraná, estados do Paraná e Mato Grosso do Sul, Brasil. In Universidade Estadual de Maringá, Nupélia/Peld. (Orgs.). A planície de inundação do alto rio Paraná: Site 6. Maringá: Nupélia. p. 197-201. Available from: <http://www.peld.uem.br/Relat2002/index02.htm>. Access in: 14 de Junho de 2005.

SOUZA, MC., KITA, KK., SLUSARSKI, SR., TOMAZINI, V., PEREIRA, GF., FONTANA, AC. and ZAMPAR, R., 2005. Vegetação ripária (Mata Ciliar). In Universidade Estadual de Maringá, Nupélia/PELD (Org.). A planície de inundação do alto rio Paraná: Site 6. Maringá: PELD/CNPq. p. 190-205. Relatório anual 2005. Available from: <http://www.peld.uem. br/Relat2005/pdf/19_VegetacaoRiparia2005a.pdf>. Access in: 04 de Novembro de 2007.

SOUZA, MC. and MONTEIRO, R., 2005. Levantamento florístico em remanescente de floresta ripária no alto rio Paraná: 
Mata do Araldo, Porto Rico, Paraná, Brasil. Acta Scientiarum, vol. 4, no. 27, p. 405-414.

STRAUBE, FC. and BIANCONI, GV., 2002. Sobre a grandeza e a unidade utilizada para estimar esforço de captura com utilização de redes-de-neblina. Chiroptera Neotropical, vol. 1-2, no. 8 , p. $150-152$.

VAN DER PJIL, L., 1957. The dispersal of plants by bats (Chiropterochory). Acta Bothanic of Neerland, vol. 6, p. 291-315.
VAZZOLER, AEAM., AGOSTINHO, AA. and HAHN, NS. (Eds.), 1997. A planície de inundação do alto rio Paraná: aspectos físicos, biológicos e socioeconômicos. Maringá: EDUEM; Nupélia. 460p.

VIZOTO, LD. and TADDEI, VA., 1973. Chave para determinação de quirópteros brasileiros. Boletim de Ciências, vol. 1, p 1-72.

ZORTÉA, M., 2007. Subfamília Stenodermatinae. In REIS, NR., PERACCHI, AL., PEDRO. WA. and LIMA, IP. (Eds.). Morcegos do Brasil. Londrina: Nelio Roberto dos Reis. p. 107-128. 